\title{
Perceptions of ICT use in rural Brazil: Factors that impact appropriation among marginalized communities
}

Paola Prado

J. Alejandro Tirado-Alcaraz

Mauro Araujo Câmara
Roger Williams University, United States

pprado@rwu.edu

Roger Williams University, United States

Corresponding Author.

jtirado-alcaraz@rwu.edu

Federal University of Minas Gerais, Brazil mauro.camara@gmail.com

This study of digital inclusion among the rural poor examines how residents of remote mountain communities in Brazil perceive the use of information and communication technologies (ICTs). It analyzes social factors that impact ICT appropriation and the behaviors and attitudes that advance digital literacy among marginalized rural populations. The authors conducted factor analysis and logistic regressions to survey data collected. Results confirm the presence of a gender divide in ICT adoption. Women were more likely to perceive that ICT use brings social benefits to the community, and considered that ICTs provide better opportunities for the young.

\section{Introduction}

Despite the hopes expressed at the 2003 and 2005 World Summits on the Information Society (WSIS) that digital inclusion policies would broaden information access in remote regions of the globe, help strengthen democracy, and foster human development among the poor, a digital divide persists amid the rapid diffusion of information and communication technology (ICT) adoption in the developing world. Starting in the mid-1990s, community

Prado, P., Tirado-Alcaraz, J.A., Araujo Câmara, M. (2016). Perceptions of ICT use in rural Brazil: factors that impact appropriation among marginalized communities. The Journal of Community Informatics, 12(3), 122-137.

Date submitted: 2015-09-20. Date accepted: 2016-06-06.

Copyright (C), 2016 (the authors as stated). Licensed under the Creative Commons AttributionNonCommercial-ShareAlike 2.5. Available at: www.ci-journal.net/index.php/ciej/article/view/1273 
telecenters and public access points proliferated throughout Latin America to provide Internet connectivity for marginalized populations. Over the past decade, many of these initiatives have collapsed under the burden of structural, political, economic, social, or other obstacles. Furthermore, and as predicted by Norris (2001), digital inclusion policies at times aggravated existing patterns of social stratification and failed to generate equal opportunities for development. As more and more public access initiatives are shuttered or abandoned, and growing numbers of users connect to the Internet from home or via mobile technologies, there is growing evidence that the model of public access telecenters as nodes for digital inclusion may be in crisis.

In Brazil as elsewhere in Latin America, ICT appropriation and Internet access have risen apace since the adoption of e-government initiatives and universal access policies in the mid to late 1990s, yet substantial challenges to digital inclusion persist, due to overarching patterns of social, economic, and structural inequalities (Olinto \& Fragoso, 2011). Political interests, societal structures, and corporate profiteering have conspired to delay the rollout of universal access initiatives and exacerbate the digital divide (Prado, 2012). Still, there is evidence that digital inclusion initiatives can impact remote and isolated communities by creating opportunities for entertainment, civic participation, and professional capacitybuilding that may foster human development, build social capital, and connect communities to global society (Gomez \& Baron-Porras, 2011; Prado, 2011; Prado, Camara, \& Figueiredo, 2011; Baron-Porras \& Gomez, 2012).

In this context, and informed by Wilson's (2004) strategic re-structuring (SRS) model, the present study seeks to further our understanding of how individual perceptions impact ICT adoption in remote rural mountain regions, where digital exclusion remains most pronounced. The issue is of significance because as researchers examine how marginalized populations perceive the practice of digital literacy, they can better understand the factors that impact the sustainability of initiatives that promote universal access and digital inclusion.

\section{Literature review}

Scholars in the field of community informatics and ICT for development who seek to theorize ICT adoption increasingly examine not only the attitudes and behaviors of ICT users, but also those of the communities and networks in which they reside. There is growing consensus that studies that expand on diffusion of innovations and development communication models with theories of social capital provide a more comprehensive framework for understanding community informatics, as proposed by Simpson (2005). In a similar vein, Gurstein (2011) called for new theoretical and conceptual models in community informatics to incorporate the community-level processes familiar to development communication frameworks in order to better examine all the factors that lead to successful ICT adoption. In addition, his call for a Freirean approach to community informatics, invites us to consider, in this study how recent rapid ICT adoption coexists apace with longstanding patterns of inequality.

\section{Internet Access in Brazil}

Almost one-half of the 277 million Internet users in South America are in Brazil, where in mid-2016 67.5\% of the population was online (Internet World Stats, 2016). The nation's adoption of universal access provisions into law in 2011 (Codigo Civil Lei 12.527), which 
codified information access as a civil right, encouraged investment in the sector. As telecommunications companies sought to expand the consumer market for home computing and mobile devices among the working poor and lower income populations, Internet connectivity rolled out to remote and marginalized communities in response to pent-up demand in settings where fixed telephone lines were few, unaffordable, or unavailable. Yet, while metrics for time spent online, social media subscriptions, and the use of communication and search functions confirm the rapid rise in Internet adoption in Brazil, Internet access remains strongly correlated to educational attainment and income (Olinto \& Fragoso, 2011). This trend lends cause for concern; all the more so in light of research that shows growing emphasis worldwide on ICT functionality and services that privilege consumerism further accentuates the digital exclusion among low-income populations (Gandy, 2002).

\section{Perceptions on the use of the Internet and Data Literacy}

Scholars have identified that persistent challenges in the quest for sustainability of community informatics initiatives in the developing world can be borne out of structural limitations (availability and accessibility of hardware and software, maintenance, upgrades, replacement, etc.), financial encumbrances (affordable capital and human resources, electrical power, physical facilities), socio-cultural constraints (training, motivation, societal acceptance) and more (Gurstein, 2011; Mossberger, Tolbert, \& Stansbury, 2003; Norris, 2001; Servaes, 2012; Servon, 2002; van Dijk, 2005; Angello, 2015). Whereas structural and economic concerns pose steep barriers to ICT adoption in many rural communities, socio-cultural dynamics have been also shown to hinder the sustainable diffusion of ICTs.

As early as 1999, Van Dijk (1999) categorized four major challenges to ICT use, and included among them individual criteria such as unfamiliarity with the logic of ICT interfaces, and the lack of relevant and engaging content as reasons for discouragement among new learners' lack of opportunity to engage with ICTs. Ample evidence has since surfaced to indicate that low levels of standard literacy and educational attainment, language barriers, and expectations of conformity regarding traditional age and gender roles, can deter individuals from the practice of digital literacy (Proenza et al., 2001; Roman \& Colle, 2002; Warschauer, 2003). It has been established that this skills gap is particularly wide among populations hindered by structural inequalities, and intensifies the persistence of a digital divide among the poor (Van Dijk \& Hacker, 2003; Gudmunsdottir, 2010; Newman et al., 2010). Furthermore, as Tygel and Kirsch (2015) remind us, data are the product of a social construction that require the audience be able to read critically and contextually. In settings where social position predetermines one's participation in economic networks, access to knowledge is inevitably stratified. Provided limited access to ICTs and absent social and cultural capital that support ICT use, marginalized populations may lack the skills or motivation to engage in data literacy.

Equally relevant to the topic is the work of Bhargava, et al. (2015), who highlight the importance of data literacy as a tool to promote empowerment and government accountability, as well as way to fight social exclusion and more. Among the challenges of promoting data literacy via public policy, the authors noted that the concept can be misconstrued or can be difficult to properly assess. Their definiton of data literacy as a willingness and ability to use data for civic engagement implies that, beyond the technical skills to know how to access data, individuals must also know what to do with data in order to bring positive changes to society. As digital technologies become prevalent they also increasingly play gatekeeper to 
economic opportunities and social inclusion. Absent data literacy, and its ensuing affordances, inequality endures among disadvantaged groups (Newman et al., 2010).

Thus, the proposition that data literacy serves as a catalyst for social change requires further analysis, particularly in those marginalized communities where the limited access to ICTs has contributed to an increasing digital divide. Wherever Internet access is available in remote and impoverished areas, the extent to which an individual will use data for the benefit of her community will be mediated by her perception about Internet use and by the social dynamics of the community where she lives.

In order to further understand the socio cultural dynamics that impact ICT adoption among the rural poor, this study set out to examine how individuals in remote rural communities perceive Internet use, and to analyze the factors that impact those perceptions.

\section{Methods}

The following is a description of the methods used in the analysis of the factors that motivate individuals to appropriate ICTs and the behaviors and attitudes that advance both data literacy and digital literacy in remote rural communities. Between May 17 and 22, 2012, trained facilitators collected data from residents in the mostly agricultural communities of Tombadouro and São Gonçalo do Rio das Pedras, in Minas Gerais, Brazil, using an interviewer-assisted survey. Each of these villages averages an estimated population of 1,000 residents, the majority of whom subsist from agricultural, extractivist, or tourism related economic activities. Respondents were required to provide written consent, and parental consent was obtained for those under the age of 18 . The survey was administered with a systematic point sampling technique and it provides a statistically valid representation of the sampled population.

Since one of the primary interests of this research was to categorize individual perception about the use of the Internet across a few general categories, factor analysis was applied to survey data that measured perception of the Internet with a Likert scale for each of the following 10 items:

(1) It helped solve problems in the community (q11a)

(2) It caused quarrels in the community (q11b)

(3) It helped prepare young people for today's world (q11c)

(4) It brought the community together to share news and information (q11d)

(5) It opened new markets for local products (q11e)

(6) It encouraged young people to look for jobs outside the community (q11f)

(7) It helped girls learn how to avoid pregnancy (q11g)

(8) It helped some people, not everybody (q11h)

(9) It made the government more responsive to us (q11i) 
(10) It brought much good to the community (q11j)

Principal components factoring was applied to extract the initial factors. As observed in Table 1 and $1 \mathrm{bis}$, the first four components have eigenvalues greater than 1 and they explain about $70 \%$ of the combined variance of all 10 variables. The decision of the number of factors to be extracted is depicted graphically in Figure 1.

Table 1: Factor analysis under principal components

$\begin{array}{llll}\text { Factor analysis/correlation } & \text { Number of obs } & = & 145 \\ \text { Method: principal-component factors } & \text { Retained factors } & = & 4 \\ \text { Rotation: (unrotated) } & \text { Number of params } & = & 34\end{array}$

\begin{tabular}{|c|c|c|c|c|}
\hline Factor & Eigenvalue & Difference & Proportion & Cumulative \\
\hline Factor 1 & 3,08 & 1,34 & 0,31 & 0,31 \\
\hline Factor 2 & 1,73 & 0,54 & 0,17 & 0,48 \\
\hline Factor 3 & 1,19 & 0,16 & 0,12 & 0,60 \\
\hline Factor 4 & 1,03 & 0,26 & 0,10 & 0,70 \\
\hline Factor 5 & 0,77 & 0,11 & 0,08 & 0,78 \\
\hline Factor 6 & 0,66 & 0,20 & 0,07 & 0,85 \\
\hline Factor 7 & 0,46 & 0,05 & 0,05 & 0,89 \\
\hline Factor 8 & 0,41 & 0,07 & 0,04 & 0,94 \\
\hline Factor 9 & 0,35 & 0,05 & 0,03 & 0,97 \\
\hline Factor 10 & 0,30 & & 0,03 & 1,00 \\
\hline
\end{tabular}

LR test: independent vs. saturated: $\quad$ chi2 $(45)=380.08 \quad$ Prob $>$ chi $2=0.0000$

Table 1bis : Factor analysis under principal components: Factor loadings (pattern matrix) and unique variances

\begin{tabular}{|c|c|c|c|c|c|}
\hline Variable & Factor 1 & Factor 2 & Factor 3 & Factor 4 & Uniqueness \\
\hline q11a & 0,66 & 0,41 & $-0,01$ & 0,05 & 0,39 \\
\hline q11b & $-0,06$ & 0,20 & 0,58 & 0,69 & 0,14 \\
\hline q11c & 0,66 & $-0,51$ & 0,01 & $-0,14$ & 0,28 \\
\hline q11d & 0,76 & 0,06 & 0,05 & $-0,33$ & 0,30 \\
\hline q11e & $-0,17$ & 0,41 & 0,60 & $-0,37$ & 0,31 \\
\hline q11f & 0,55 & $-0,60$ & 0,20 & $-0,04$ & 0,30 \\
\hline q11g & 0,35 & $-0,48$ & 0,55 & 0,08 & 0,35 \\
\hline q11h & 0,33 & 0,57 & 0,26 & $-0,36$ & 0,38 \\
\hline
\end{tabular}




\begin{tabular}{|l|l|l|l|l|l|}
\hline Variable & Factor $\mathbf{1}$ & Factor 2 & Factor 3 & \multicolumn{1}{l}{ Factor 4 } & Uniqueness \\
\hline $\mathbf{q 1 1 i}$ & 0,77 & 0,18 & $-0,13$ & 0,29 & 0,27 \\
\hline $\mathbf{q 1 1 j}$ & 0,68 & 0,40 & $-0,26$ & 0,26 & 0,24 \\
\hline
\end{tabular}

Figure 1: Rotation of the factor structure.

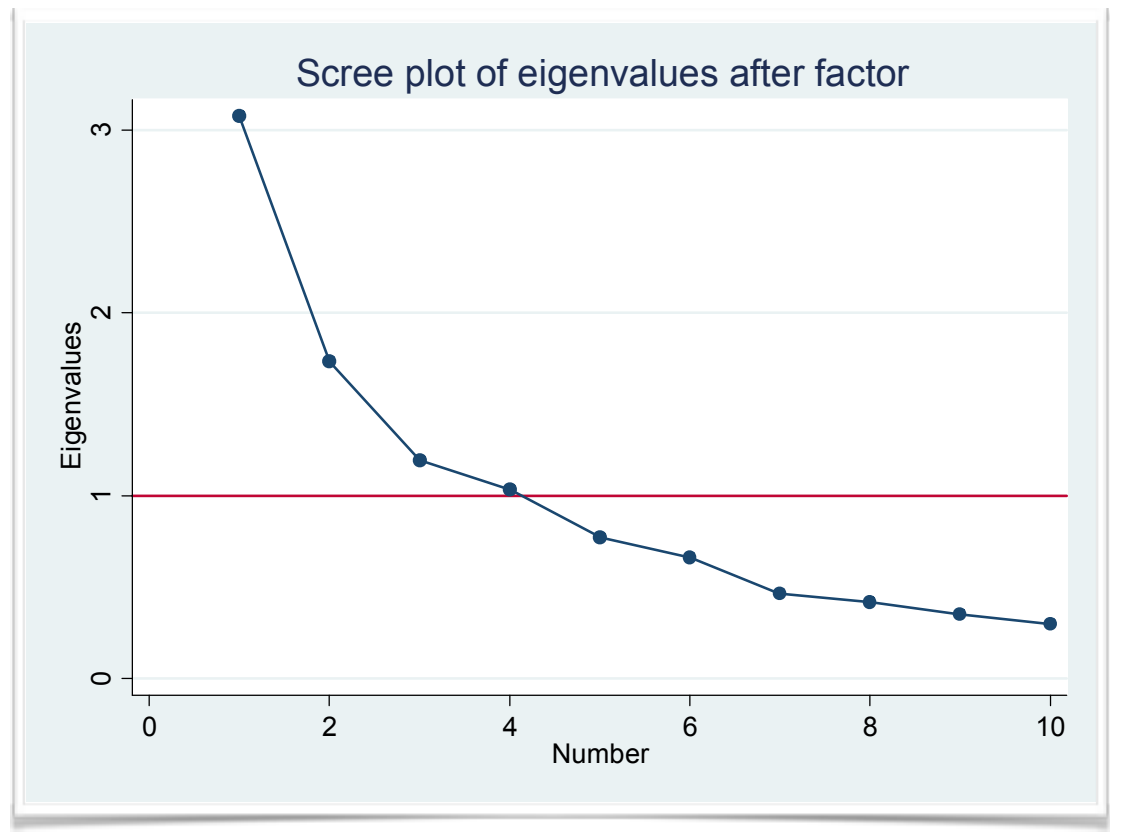

The next step was the rotation of the factor structure using the varimax method. As shown in Figure 1, variables q11a, q11d, q11i and q11j load higher on factor 1 (marked by the red horizontal line). All these variables refer to benefits for the community. As for factor 2 , variables q11c, q11f, and q11g load most heavily on it. It is interesting to note that all of these variables are related to benefits for the youth. In the case of factor 3, all variables associated with it refer to economic benefits: q11e and q11h. Finally, the last factor is basically made of variable q11b, which can be associated with a negative perception on the use of Internet.

\section{Results}

Tables 2, 2bis and 2plus shows the results for the extraction of the four factors and the variables associated with it. The imagery of this procedure is provided in Figure 2. Based on the results from factor analysis, we observe that individual perception of Internet use in these communities can be classified in four broad categories: social benefits for the community, opportunities for the youth, economic benefits for the community, and negative impact for the community. The questions that emerge from these results are: which of these factors did respondents consider most relevant for the community, and whether people in general share the same perception, or whether perception of Internet use varies within the community according to social markers such as gender. The answers to these questions could shed light not only on how people in marginalized communities think about the use of Internet, but also on the likelihood and patterns for Internet appropriation, and the potential for data literacy. These are questions this study explored through the use of regression models. 
Table 2: Extraction of factors with eigenvalues greater than 1

Factor analysis/correlation

Method: principal-component factors

Rotation: orthogonal varimax (Kaiser on)
Number of obs $=145$

Retained factors $=4$

Number of params $=34$

\begin{tabular}{|l|l|l|l|l|}
\hline Factor & Eigenvalue & Difference & Proportion & \multicolumn{1}{c|}{ Cumulative } \\
\hline Factor 1 & 2,54 & 0,48 & 0,25 & 0,25 \\
\hline Factor 2 & 2,06 & 0,77 & 0,21 & 0,46 \\
\hline Factor 3 & 1,29 & 0,15 & 0,13 & 0,59 \\
\hline Factor 4 & 1,14 & & 0,11 & 0,70 \\
\hline
\end{tabular}

LR test: independent vs. saturated: $\quad$ chi2 $(45)=380.08 \quad$ Prob $>$ chi $2=0.0000$

Table 2bis: Factor loadings (pattern matrix) and unique variances

\begin{tabular}{|l|l|l|l|l|l|}
\hline Variable & Factor $\mathbf{1}$ & Factor $\mathbf{2}$ & Factor 3 & Factor 4 & Uniqueness \\
\hline q11a & 0,74 & 0,08 & 0,22 & 0,01 & 0,39 \\
\hline q11b & 0,07 & $-0,01$ & 0,07 & 0,92 & 0,14 \\
\hline q11c & 0,26 & 0,75 & $-0,14$ & $-0,26$ & 0,28 \\
\hline q11d & 0,55 & 0,45 & 0,30 & $-0,32$ & 0,30 \\
\hline q11e & $-0,18$ & $-0,08$ & 0,79 & 0,15 & 0,30 \\
\hline q11f & 0,11 & 0,82 & $-0,13$ & $-0,06$ & 0,35 \\
\hline q11g & $-0,06$ & 0,75 & 0,07 & 0,28 & 0,38 \\
\hline q11h & 0,38 & $-0,06$ & 0,68 & $-0,08$ & 0,27 \\
\hline q11i & 0,81 & 0,22 & $-0,11$ & 0,07 & 0,24 \\
\hline q11j & 0,87 & $-0,03$ & $-0,06$ & 0,01 & \\
\hline
\end{tabular}

Table 2plus: Factor rotation matrix

\begin{tabular}{|l|l|l|l|l|}
\hline & Factor 1 & Factor 2 & Factor 3 & Factor 4 \\
\hline Factor 1 & 0,81 & 0,57 & 0,06 & $-0,13$ \\
\hline Factor 2 & 0,47 & $-0,70$ & 0,52 & 0,14 \\
\hline Factor 3 & $-0,25$ & 0,42 & 0,63 & 0,61 \\
\hline Factor 4 & 0,24 & $-0,11$ & $-0,58$ & 0,77 \\
\hline
\end{tabular}




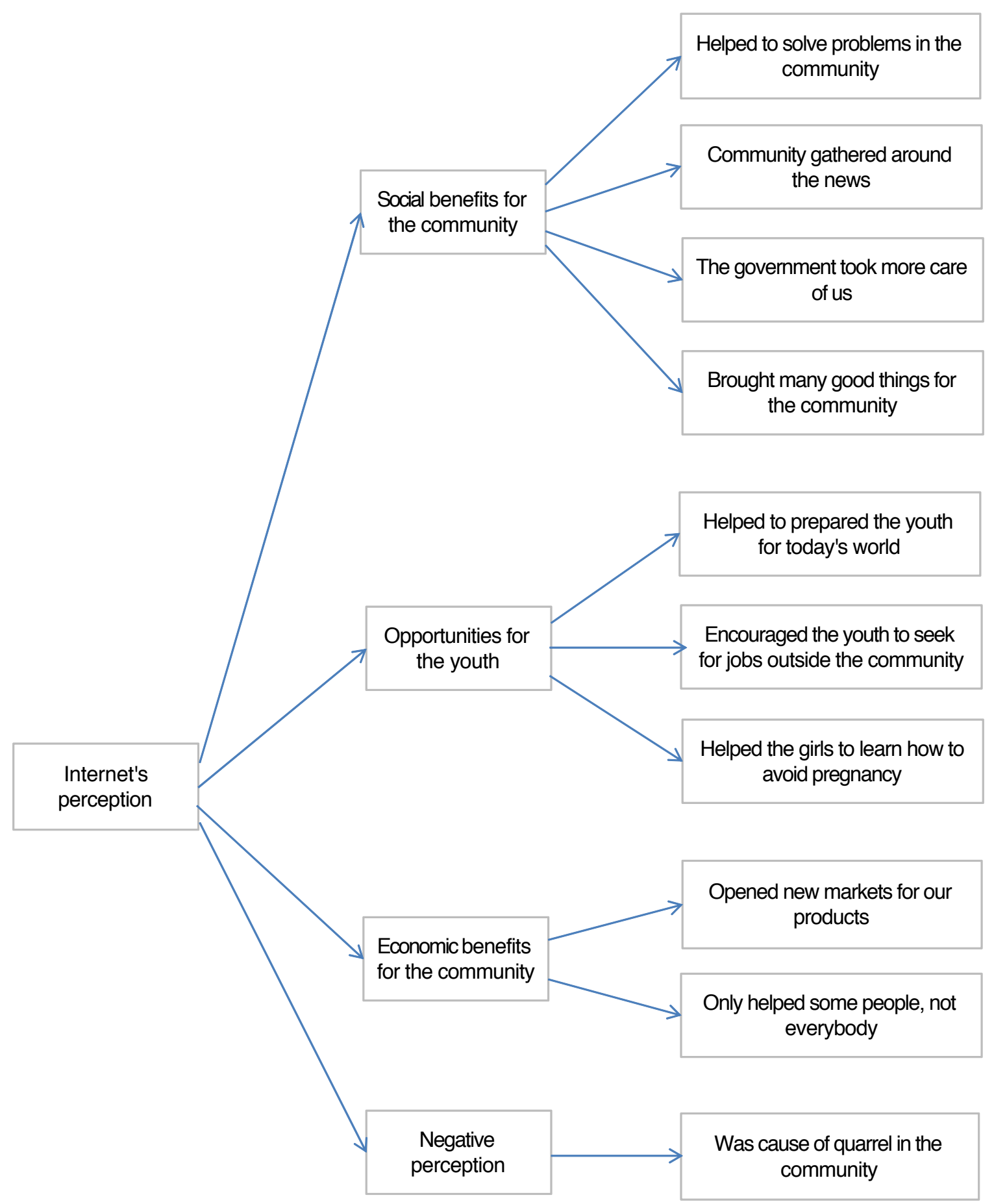

Figure 2: Factor analysis on people's perception about the use of the Internet

In the manner proposed by Kyung and Wang-Bae (2004), we performed a multinomial logit model of the determinants of individual perception of Internet use including demographic factors only. The results show that gender, age, and educational attainment impact the perception of Internet use. Furthermore, the findings indicate that this perception can conform to one of the four categories uncovered previously with factor analysis techniques: social and economic benefits for the community in general, better opportunities for the youth only, or negative perception. Figure 3 depicts this model. 


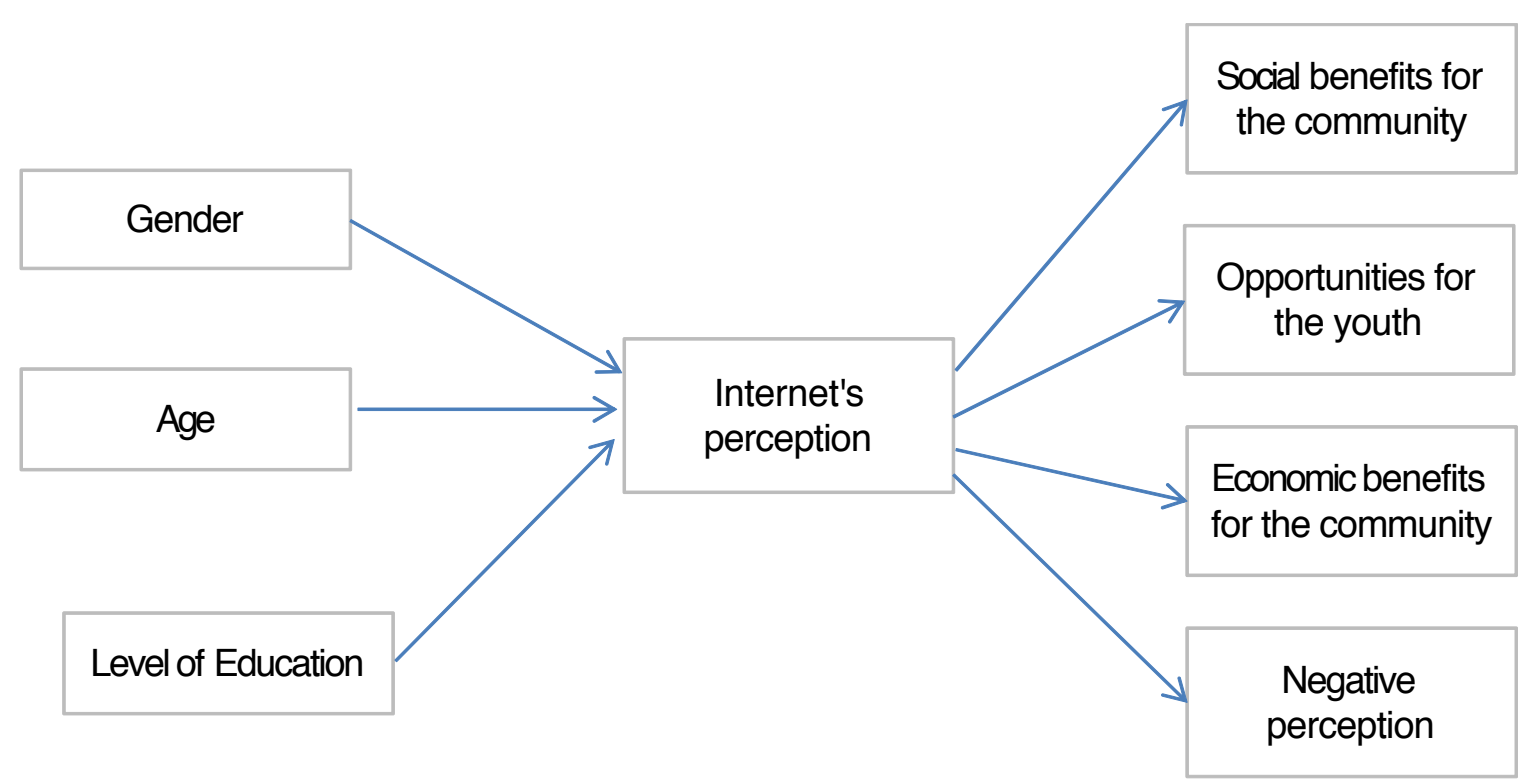

Figure 3: Perception of Internet use model

Previous studies have shown how the use of mobile telephony and Internet separately may increase the productivity of microbusinesses in ways that bring positive economic effects to small communities. This, in turn, can contribute to deliver better sources of information and communication to the population (Huaroto, 2012; Barrantes Cáceres, Agüero, \& Cavero, 2012). However, the underlying assumption in each case is that people with access to ICTs will automatically experience positive social change, without regard of ex-ante perceptions that might condition ICT adoption.

One of the interests of this study is to further explore how people's perception impacts the use of the Internet via mobile telephony. A separate regression model was used to estimate this, where the dependent variable is a latent variable that refers to individual use of Internet on a mobile phone. This was operationalized through a proxy variable in question 3 , which refers to the use of the Internet via mobile phone as one of the reasons for not visiting the telecenter. Future studies may consider a more adequate proxy.

As for the explanatory variables, besides people's perception of the use of Internet, demographic variables were also included (age, gender, and level of education). Since the dependent variable is related with the reasons for not going to the telecenter it is important to control for other factors, such as having a computer at home.

\section{Discussion}

The results of the multinomial logit are shown in Table 3. The last four columns refer to each of the broad categories related to individual perception of Internet use. For instance, the second column, base outcome, refers to individuals who perceive that use of the Internet brings social benefits for the community. The regression in the third column refers to individuals who think that use of the Internet brings opportunities for the youth. Column four shows a similar regression for those who perceive that use of the Internet can bring economic benefits for the community, and column five shows those who have a negative perception about Internet use. 
Table 3: Multinomial logit of people's perception of the use of the Internet on different demographic factors.

\begin{tabular}{|c|c|c|c|c|}
\hline $\begin{array}{l}\text { Dependent Variable: } \\
\text { People's Internet } \\
\text { Perception }\end{array}$ & $\begin{array}{l}\text { Social Benefits for the } \\
\text { Community }\end{array}$ & $\begin{array}{l}\text { Opportunities for the } \\
\text { Youth }\end{array}$ & $\begin{array}{l}\text { Economic Benefits for } \\
\text { the Community }\end{array}$ & $\begin{array}{l}\text { Negative Perception of } \\
\text { the Internet }\end{array}$ \\
\hline \multirow[t]{2}{*}{ Variable / Coefficient } & (Base outcome) & & & \\
\hline & $\mathrm{b}$ & $\mathrm{b}$ & $\mathrm{b}$ & $\mathrm{b}$ \\
\hline \multicolumn{5}{|l|}{ Gender } \\
\hline Female $=1$, Male $=0$ & & $-1.17 * *(0.50)$ & $-0.95 *(0.50)$ & $-1.57 * * *(0.60)$ \\
\hline \multicolumn{5}{|l|}{ Age } \\
\hline (Years) & & $-0.01(0.03)$ & $-0.06(0.04)$ & $0.02(0.02)$ \\
\hline Level of Education & & & & $0.02(0.02)$ \\
\hline $\begin{array}{l}\text { Finished Lower } \\
\text { School }\end{array}$ & & $0.79(0.70)$ & $0.25(0.60)$ & $1.00(0.91)$ \\
\hline Finished High School & & $1.62 * *(0.72)$ & $1.20 *(0.69)$ & $1.35(0.92)$ \\
\hline Finished College & & $3.28 * * *(1.09)$ & $2.66 * *(1.22)$ & $2.61 * *(1.28)$ \\
\hline Constant & & $-0.46(0.77)$ & $0.87(0.78)$ & $-1.40(0.95)$ \\
\hline Log Likelihood & $-179,53$ & $* \mathrm{p}<0.1$ & $* * \mathrm{p}<0.05$ & $\begin{array}{l}* * * \mathrm{p}<0.001, \text { (one-tail } \\
\text { test) }\end{array}$ \\
\hline $\mathbf{N}$ & 145 & $\begin{array}{l}\text { (standard errors are in } \\
\text { parentheses) }\end{array}$ & & \\
\hline
\end{tabular}

Base category for education: Unfinished lower school

The estimates indicate that women were more inclined than men to perceive that Internet use provides social benefits for the community over and above all else. In the category related to education, results show that, in general, individuals with higher levels of education are more likely to perceive that use of Internet provides more opportunities for the youth or more economic benefits for the community.

The regression model of Internet use with mobile phones is also a probabilistic model. Given the characteristics of the dependent variable, we estimated a simple logit model (see regression output in Table 4). Not surprisingly, there was a lower probability that individuals with a negative perception of the Internet would check the Internet on their mobile phones. Results also show that women were less likely than men to surf the Internet on their mobiles. As for the level of education, people with a college degree were more likely to check the Internet on their mobile phones than those who did not finish lower school. Other factors were not found to be statistically significant at the 0.05 level. 
Table 4: Logit model of the use of Internet through cellular phone.

Dependent Variable: $\quad$ Use of the Internet through mobile

\begin{tabular}{|c|c|}
\hline \multicolumn{2}{|l|}{ Covariates } \\
\hline \multirow[t]{2}{*}{ Social benefits for the community } & -0.02 \\
\hline & $(-0.04)$ \\
\hline \multirow[t]{2}{*}{ Opportunities for the youth } & 0.11 \\
\hline & $(0.38)$ \\
\hline \multirow[t]{2}{*}{ Economic benefits for the community } & -0.19 \\
\hline & $(-0.53)$ \\
\hline \multirow[t]{2}{*}{ Negative perception of the Internet } & $-2.16^{*}$ \\
\hline & $(-2.14)$ \\
\hline \multirow[t]{2}{*}{ Gender } & $-1.61^{*}$ \\
\hline & $(-2.11)$ \\
\hline \multirow[t]{2}{*}{ Age } & -0.10 \\
\hline & $(-1.46)$ \\
\hline \multicolumn{2}{|l|}{ Level of education } \\
\hline \multirow[t]{2}{*}{ Finished lower school } & 1.42 \\
\hline & $(1.18)$ \\
\hline \multirow[t]{2}{*}{ Finished high school } & 1.56 \\
\hline & $(1.15)$ \\
\hline \multirow[t]{2}{*}{ Finished college } & $4.01 *$ \\
\hline & $(2.10)$ \\
\hline \multirow[t]{2}{*}{ Computer at home } & -1.19 \\
\hline & $(-1.74)$ \\
\hline \multirow[t]{2}{*}{ Constant } & -0.88 \\
\hline & $(-0.59)$ \\
\hline Observations & 145 \\
\hline
\end{tabular}

Finally, Table 5 provides a list of different measures of fit. When comparing the loglikelihood of the model with the intercept only (-69.698) with that of the full model (-59.710), it is observed that that the full model provides a better fit. Also, Table 5 provides the likelihood ratio chi-squared (19.976), which tests whether the model with10 covariates makes better predictions than the model with the intercept only. The degrees of freedom are given the 
number of covariates in the full model (10). The p-value for this chi-squared is 0.029 . Based on this, it is possible to reject the null hypothesis that the model with the intercept predicts better than the full model. In other words, the full model is a better fit. It is worth noting that the estimated variance for our latent dependent variable is 4.488 . This is the proportion of change due to the variation of the covariates.

Table 5: Measures of fit of the logit model of the use of the Internet through mobile

\begin{tabular}{|l|r|l|l|r|}
\hline Log-Lik Intercept Only: & $-69,7$ & Log-Lik Full Model: & $-59,71$ \\
\hline D(134): & 119,42 & LR(10): & 19,98 \\
\hline McFadden's R2: & & Prob > LR: & 0,03 \\
\hline ML (Cox-Snell) R2: & 0,14 & Mcfadden's Adj R2: & $-0,01$ \\
\hline McKelvey \& Zavonia's R2: & 0,13 & Cragg-Uhler (Nagelkerke) R2: & 0,21 \\
\hline Variance of y*: & 0,27 & Efron's R2: & 0,15 \\
\hline Count R2: & 4,49 & Variance of error: & 3,30 \\
\hline AIC: & 0,82 & Adj Count R2: & 0,04 \\
\hline BIC: & 0,98 & AIC*n: & 141,42 \\
\hline BIC used by Stata: & $-547,46$ & BIC': & 29,79 \\
\hline
\end{tabular}

The existence of a gender divide in ICT use has been widely documented; over the past decade, researchers have pinpointed the various challenges to adoption and identified contradictory factors that contribute to the persistence of this gap (Best \& Maier, 2007; Broos, 2005; Hilbert, 2011; Lennie, 2002). The present study corroborates that evidence, having found that gender and education impact one's perceptions of ICT use. The results show that women are likely to perceive the benefits of ICT differently from men. The findings also indicate that women are less likely to rely on mobile connectivity to access the Internet. Overall, the findings lend support that, ICT adoption is not gender neutral and that successful digital inclusion requires minimal educational standards be met (Ghosh, 2009). For women to participate effectively in an increasingly digital society, structural access to ICTs is a first step, but instruction in data literacy must follow.

The effect of education is of particular interest since around 67 percent of the respondents showed low levels of educational attainment. This confirms previous findings by Olinto and Fragoso (2011) and introduces two possible outcomes: Internet use and data literacy can either drive positive social change or it can contribute to a dystopia. The first outcome is expected when individuals are engaged with their communities and become actors of social change through data use. The second outcome is likely to happen when data literacy exacerbates existing structural problems like inequality and social exclusion (Bhargava, et al., 2015). Whereas previous research by Gandy (2002) examines the latter case scenario, Prado, Camara, and Figueiredo (2011) previously found that ICT use promoted entertainment as well as civic engagement and professional development in these very communities. If education 
contributes to a more positive perception and increased Internet use, then greater investments in digital inclusion might reduce inequality.

This study found that women were more likely than men to perceive Internet use as a source of information sharing and collaboration that was beneficial to the social and economic life of their community. On the other hand, women were less likely to perceive the Internet as valuable source of opportunity for the young. These results hint at a limited grasp of the potential of the Internet. They may reflect the consequences borne out of lower rates of ICT adoption and data literacy among the women. Absent the knowledge, exposure, and skill sets, women would be less likely to value a content they do not thoroughly understand or know. Whereas women are able to see the Internet as a new educational and informational tool, their limited data literacy undermines their grasp of its capabilities as a tool for economic or professional development. This would seem to be the case, given that better educated individuals were found to perceive the economic benefits of the Internet for the community and for its youth. Those same individuals were, however, less likely to see Internet use as otherwise beneficial to the social life of the community.

The above findings are of concern because social capital has been shown to play an important role in facilitating ICT adoption by rural women in the developing world (Huyer \& Sikuska, 2003). Furthermore, individual motivation and self-interest have been found to be key markers among community leaders who champion ICT use Wilson (2004). Absent these qualities, ICT adoption is less likely to take hold. The gender gap in perceptions of ICT use suggests an existing disparity in access to skills and knowledge among women and men. It also identifies how a gap in educational attainment manifests in a poor understanding of the capabilities and potential that can result from digital inclusion and data literacy.

\section{Conclusions}

In 2015, when more than three billion people in the world could connect to the Internet, mobile-cellular subscriptions worldwide reached more than seven billion (ITU, 2015). As mobile connectivity becomes increasingly available in rural areas and the next generation of Internet-enabled devices looms, more attention must be paid to the gender gap in mobile ICT adoption. Insofar as the persistence of a gender divide in rural communities impacts digital inclusion and data literacy, it presents an obstacle to the promotion of human development in these areas of the developing world.

The findings in this study expand our understanding of the nature and scope of ICT adoption among the rural poor. They are nonetheless limited by the small sample sizes and limited geographic scope of this study. More research is needed to understand the extent to which the gender gap impacts ICT adoption in remote rural communities.

\section{References}

Angello, Consolata (2015). "Exploring the use of ICTs in learning and disseminating livestock husbandry knowledge to urban and peri-urban communities in Tanzania." International Journal of Education and Development using Information and Communication Technology (IJEDICT), 11 (2), 5-22. 
Bhargava, R., Deahl, E., Letouzé, E., Noonan, A., Sangokoya, D., \& Shoup, N. (September 2015). Beyond Data Literacy: Reinventing Community Engagement and Empowerment in the Age of Data. Data-Pop Alliance White Paper Series. Data-Pop Alliance (Harvard Humanitarian Initiative, MIT Lad and Overseas Development Institute) and Internews.

Baron-Porras, L.F.; Gomez, R. (2012). "Same But Different: Comparing Public Access Computing Venues in Colombia." Information Technologies \& International Development. 8 (4), 43-57.

Barrantes Cáceres, R.; Agüero, A.;Cavero, M. (2012). "The Impacts of the Use of Mobile Telephone Technology on the Productivity of Micro- and Small Enterprises: An Exploratory Study into the Carpentry and Cabinet-Making Sector in Villa El Salvador." Information Technologies \& International Development. 8 (4), 77-94.

Best, M. L.; \& Maier, S. G. (2007). "Gender, Culture and ICT Use in Rural South India." Gender Technology and Development, 11( 2), 137-155.

Broos, A. (2005). Gender and information and communication technologies (ICT) anxiety: Male selfassurance and female hesitation. CyberPsychology \& Behavior, 8 (1), 21-31.

Codigo Civil Lei [Civil Code of Law] 12.527/2011. Acesso à Informação no Brasil [Access to information in Brazil]. Retrieved from http://www.planalto.gov.br/ccivil_03/ _Ato2011-2014/2011/Lei/L12527.htm

Gandy, O. (2002). The real digital divide: Citizens versus consumers. The Handbook of New Media: Social Shaping and Consequences of ICTs. 448-460. London: Sage.

Ghosh, D. D. (2009). Engendering ICTs: Scope for Empowering women, with special reference to India. The Journal of Community Informatics, 5 (3).

Gomez, R.; Baron-Porras, L.F. (2011). "Does Public Access Computing Really Contribute to Community Development? Lessons from Libraries, Telecenters and Cybercafés in Colombia." The Journal of Community Informatics, 49.

Gudmunsdottir, G.B. (2010). "From digital divide to digital equity: Learners' ICT competence in four primary schools in Cape Town, South Africa." International Journal of Education and Development using Information and Communication Technology (IJEDICT). 6 (2), 84-105.

Gurstein, M. (2011). Editorial: Community Informatics in Brazil. The Journal of Community Informatics, 7 (1-2). Retrieved from http://ci-journal.net/index.php/ciej/article/view/849/727

Gurstein, M. (2011). Telecentres are not sustainable: Get over it! ITU sponsored workshop on Telecentre sustainability in Bangkok, May 23-25, 2011. Retrieved from http:// gurstein.wordpress.com/2011/05/18/telecentres-or-community-access-centres-or-publicinterest-access-centres-or-community-technology-centres-etc-etc-are-not\%E2\%80\%9Csustainable\%E2\%80\%9D-get-over-it/\#comment-714

Hilbert, M. (2011, December). Digital gender divide or technologically empowered women in developing countries? A typical case of lies, damned lies, and statistics. In Women's Studies International Forum 34 (6), 479-489.

Huaroto, C. (2012). "Use of the Internet and Productivity of Microbusinesses: Evidence from the Peruvian Case (2007-2010)." Information Technologies \& International Development , 8 (4), 113-128.

Huyer, S.; \& Sikuska, T. (2003). Overcoming the gender digital divide: understanding ICTs and their potential for the empowerment of women. INSTRAW virtual seminar series on gender and ICTs. N0.1. http://www.un-instraw.org/en/research/gender_and_ict/virtual_seminars.html 
International Telecommunications Union [ITU] (2015). ICT Facts \& Figures. Retrieved from http:// www.itu.int/en/ITU-D/Statistics/Documents/facts/ICTFactsFigures2015.pdf

Internet World Stats (2014). Internet Users in the Americas. Retrieved June 23, 2015 from http:// www.Internetworldstats.com/stats2.htm

Lennie, J. (2002). "Rural women's empowerment in a communication technology project: some contradictory effects." Rural Society, 12 (3), 224-245.

Mossberger, K., Tolbert, C. J.; \& Stansbury, M. (2003). Virtual inequality: Beyond the digital divide. Washington, DC: Georgetown University.

Newman, L.; Biedrzycki, K., Baum, F.. (2010). Digital Technology Access and Use among Socially and Economically Disadvantaged Groups in South Australia. The Journal of Community Informatics, 6 (2).

Norris, P. (2001). Digital divide: Civic engagement, information poverty, and the Internet worldwide. Cambridge ; New York: Cambridge University Press.

Olinto, G. \& Fragoso, S. (2011). "Internet use and Community Informatics in Brazil: speeding up or lagging behind?" The Journal of Community Informatics, 7 (1-2).

Prado, P. "Favela e Roça Online: Digital Inclusion of Marginalized Urban and Rural Areas of Brazil." Presented in the Eastern Communication Association panel Bridging the Gap: Internet and Participation in the Developing World. Cambridge, Mass., April 2012.

Prado, P. (2011). "Lighting up the dark: Telecenter adoption in a Caribbean agricultural community." Journal of Community Informatics: Special Issue: Prato Community Informatics Conference: 2011, 6 (3).

Prado, P.; Camara, M. A.; Figueiredo, M.A. (2011). "Evaluating ICT Adoption in Rural Brazil: A Quantitative Analysis of Telecenters as Agents of Social Change." Journal of Community Informatics: Special Double Issue: The Internet and Community Informatics in Brazil, 2010-2011, Vol. 7 (1-2).

Proenza, F. J., Bastidas-Buch, R., \& Montero, G. (2001, May). Telecenters for Socioeconomic and Rural Development in Latin America and the Caribbean: Investment Opportunities and Design Recommendations, with special reference to Central America. Washingotn, D.C.: Inter-American Development Bank. Retrieved from http://www.iadb.org/regions/itdev/ telecentros/index.htm

Roman, R. \& Colle, R. D. (2002, July). Creating a participatory telecenter enterprise. Paper presented at the Participatory Communication Research Section in the annual meeting of International Association for Media and Communication Research, Barcelona, Spain.

Servaes, J. (2012). The sustainability of communication for social change: Back to the basics. Paper presented at the 2012 Eastern Communication Association in Cambridge, Massachussetts.

Servon, L. J. (2002). Bridging the digital divide: Technology, community, and public policy. Malden, MA: Blackwell.

Simpson, L. (2005). "Community Informatics and Sustainability: Why Social Capital Matters." Journal of Community Informatics, 1 (2).

Tygel, A. F. \& Kirsch, R. (2015). Contributions of Paulo Freire for a critical data literacy. Paper preented at the First Data Literacy Workshop at the WebScience Conference. Oxford, UK. Retrieved from http://www.dataliteracy.eita.org.br/ 
Van Dijk, J. A.G. M. (2005). The deepening divide: Inequality in the information society. Thousand Oaks, CA: Sage.

Van Dijk, J. A.G. M. (1999). The network society, social aspects of new media. Thousand Oaks, CA: Sage.

Van Dijk, J. \& Hacker, K. (2003) “The Digital Divide as a Complex and Dynamic Phenomenon.” The Information Society: An International Journal, 19 (4), 315-326.

Warschauer, M. (2003). Technology and Social Inclusion: Rethinking the Digital Divide. Cambridge, MA: MIT.

Wilson, E. J. (2004). The Information Revolution and Developing Countries. Cambridge: MIT Press.

Wresch, W. (2009). "Progress on the global digital divide: an ethical perspective based on Amartya Sen's capabilities model." Ethics of Information Technology, 11, 255-263 